\title{
Daemons in the Cave
}

\section{Plutarch on Plato and the Limits of Politics}

\author{
Mauro Bonazzi \\ Utrecht University, Dept. of Philosophy and Religious Studies \\ m.bonazzi@uu.nl
}

Received April 2018 | Accepted October 2018

\begin{abstract}
The aim of the paper is to provide a unitary reading of Plutarch's De genio Socratis by concentrating on the character of Epameinondas. Against those who claim that the philosophical speeches are the main theme of the dialogue, it is argued that Epameinondas, one of the speakers, also plays an active role in the liberation of Thebes. Against those who insist on the political action alone, it is shown that Epameinondas' commitment is not the same as that of the other conspirators. His goal-like that of Plato and Socrates (as they are represented in the text) - is to take care of his fellow citizens, and lead them to moral virtue, in accordance with the divine order. This idea may appear piously unrealistic, but it clearly illustrates the merits and limits of Plato's political philosophy.
\end{abstract}

\section{Keywords}

Plutarch of Chaeronea - Plato's political philosophy - Middle Platonism - Philosophy and Society

\section{A Philosopher Embedded in His Society}

Philosophy and society do not always go well together, as Socrates discovered and Aristotle reminded in 323 BC when he was forced to escape from Athens. ${ }^{1}$ In the Hellenistic period, however, and even more in the early Imperial age,

1 Fr. 667 Rose; see Düring 1957, 341-342. 
the situation changed for the better, and the social reputation of philosophy progressively improved. Not all problems disappeared, of course. The exile, execution and suicide of philosophers are recurrent phenomena in antiquity. The failure of individual philosophers, however, did not prevent philosophy from occupying a central position in the cultural and educational system of the Greek and Roman world. In the early Imperial age, which witnessed the diffusion of philosophical schools throughout the Greek and Roman world, philosophy progressively came to be regarded as a necessary part of paideia - philosophy was recognized as a necessary element of Greek identity (and Roman identity too, but this is more complicated). ${ }^{2}$ Its prestige was widely acknowledged by then.

This new situation had an impact on the views of many philosophers at the time. In the fourth and third centuries BC the dominant tone of philosophy seems to consist in the apology of a life devoted to detached speculation and withdrawn from the obligations of social life. Later, from Cicero to Seneca and Maximus of Tyre, the majority of philosophers - be they Stoics, Platonists or the followers of other schools - stressed the social utility of philosophy. ${ }^{3}$ One illuminating example of this trend is Plutarch of Chaeronea. Philosophy occupies a central place in his teaching activity and written production, and a distinctive feature of his philosophical activity is the emphasis on the social, political and pedagogical importance of philosophy.

Recently, scholars have greatly contributed to clarifying this aspect of Plutarch's life and thought from a variety of perspectives: it is not simply a matter of reconstructing his philosophical system but also of understanding the social dimension of his philosophical stance. With regard to this second point, by focusing on the practical treatises of Plutarch's corpus, Lieve Van Hoof has shown that he integrated philosophy with the cultural world of his time. The aim is no longer to oppose philosophy to the values of society. On the contrary, philosophy is defended "as a tool that will improve the quality of their lives [i.e. the lives of the readers of his essays] and further their social position: instead of opposing philosophy to society and thereby confronting the individual with the choice between two mutually exclusive alternatives, [Plutarch] presents philosophy in these writings as the bridge that can close the gap between individual and the society". ${ }^{4}$ The same view is also defended in the political treatises, which argue for the necessity of philosophy for a well-governed

2 Trapp 2007, 1-27 offers a very useful overview; on the diffusion of philosophical schools throughout the Mediterranean world, see Sedley 2003.

3 See Festugière 1971, 132-148; Bénatouïl and Bonazzi 2012, 9-14.

4 Van Hoof 2010, 34. 
state. Again, what we have is not an opposition between two incompatible options: the emphasis is rather on the political utility of philosophy.

The texts specifically devoted to philosophy complete the picture and concretely show what philosophy properly amounts to. At stake is not philosophy in general, but Plato's philosophy, which is the only possible philosophy for Plutarch. Whereas in the practical and political texts he argues for the superiority of philosophy against other intellectual disciplines (such as rhetoric or medicine) by showing that only philosophy can provide the necessary tools for attaining (real) success in society, in the philosophical works he explains the doctrinal coordinates of the only genuine form of philosophy, that is Platonism. ${ }^{5}$

Plutarch is usually styled as a wise and detached philanthropos, agreeable and full of human warmth. Needless to say, this is not a false portrait. ${ }^{6}$ However, a more accurate social and cultural contextualization of his intellectual production shows that he was much less naive than he is sometimes taken to be. In the intellectual market of the early Empire competition was very strong, with philosophers, rhetors, sophists and doctors "investing their own forms of cultural capital in order to reinforce social esteem for themselves and their profession". ${ }^{7}$ A man full of human warmth and a sensible philanthropist, Plutarch was also 'a clever player', capable of displaying great skill in order to gain prestige and to promote himself within society. ${ }^{8}$ For it is not simply the case that philosophy is better than rhetoric or medicine, and that Platonism is the only genuine philosophy. The point is that Plutarch embodies the real philosopher insofar as he is the most authentic and trustworthy interpreter of Plato's message.

This is a fascinating reading of Plutarch that has the great merit of putting him into his historical and cultural context. But such a reconstruction also needs to be somehow qualified for; as I will try to show, Plutarch's adoption and development of the Platonic model is not without consequences. In order to show the problems Plutarch had to face when he attempted to present his Platonism as the best philosophy for the Empire, I will concentrate on one of his most intriguing texts, the dialogue On Socrates' Daimonion (De genio Socratis). ${ }^{9}$ This dialogue has always constituted a great challenge for

5 Two useful introductions to Plutarch's Platonism are Jones 1916 and Ferrari 1995; more recently see the articles of Beck 2014, Section 2.

6 See for instance Mossman 1997, x, and Stadter 1999, 481.

7 Van Hoof 2010, 78; see also Hahn 1989, 46-53.

8 Van Hoof 2010, 263-264.

9 The Greek text is quoted according to Sieveking 1972; the translations are taken from De Lacy and Einarson 1959 . 
any reader of Plutarch: by putting it into a Platonic context, I will try to make sense of it. But this Platonic reading will also help us to see that Plutarch's position within the context of his own time is more complex than is usually assumed. ${ }^{10}$

\section{The Problem of the De genio Socratis}

It is commonly agreed that the De genio Socratis is one of the most sophisticated and successful works of Plutarch's. ${ }^{11}$ But scholars disagree as to its real meaning: what is the message that the reader is expected to draw from this narrative combining a thrilling description of the liberation of Thebes from Spartan occupation in 379 BC and a discussion on the real nature of Socrates' famous daemon? What, if any, are the central themes of the dialogue and Plutarch's message?

In the nineteenth and early twentieth centuries many scholars argued against the existence of a major theme in the dialogue. ${ }^{12}$ This trend, however, has been inverted in more recent years, and it is now correctly acknowledged that it is misleading to read the dialogue as if it were a hotchpotch of unconnected digressions. ${ }^{13}$ Sure, the problem of the unity of the text is probably more important for a modern reader than for an ancient reader, as Malcolm Heath has shown. ${ }^{14}$ But this does not exclude that, like in a musical symphony, one major theme could serve as the thread running through the text, coordinating if not all at least most of the episodes and discussions. Scholars have recently argued that this is Plutarch's authorial strategy. ${ }^{15}$ Indeed, it is typical of him to organize his material in such a way that it is up to the reader to decipher its structure, and it is a reasonable assumption that this also holds in the case of the De genio. ${ }^{16}$ The problem, then, is to establish what the main theme is around which most of the dialogue is built. One option is the political narrative: in spite of the title of the work, Plutarch's real aim would be to

10 With regard to the Quaest. conv. see König 2011, who explores the tension between the need for individual self-promotion and subordination to the wider sympotic community.

11 Two recent and useful editions are Nesselrath 2010 and Donini 2017.

12 Cf. for instance Ricard 1844, vol. 3, 73; Kahle 1912, 88; Croiset 1928, 495; Raingeard 1935. A detailed list is in Barigazzi 1994, 214-220 with further references.

13 As for instance argued by Ziegler 1964, 204, who described the connection between the narrative and the discourses as 'superficial and artificial'.

14 Heath 1989.

15 See now Donini 2017, 9-14 (with an interesting comparison between the De genio Socratis and another important philosophical text, the De facie in orbe lunae).

16 Babut 1984, 54. More generally, see König 2007. 
celebrate the glorious days of the revolt which led to Theban hegemony over the Greek world in the subsequent decade (371-362 BC). This reading, supported by many scholars at the beginning of last century, ${ }^{17}$ has been recently contested, and with good reasons. In effect, the main support for such a hypothesis seems to rest on the claim that a dismissal of this cardinal event in Theban history cannot be attributed to the patriotic Plutarch, so proud of his Boeotian origins. But the claim is unfounded for several reasons. First of all, to deny that the liberation of Thebes is not the central theme is not to say that it is dismissed or, even worse, viewed in a negative light. ${ }^{18}$ It is probably correct that Plutarch sympathizes with the liberation of the city, but this does not imply that it is the central theme, as a second look at the text suggests. The problem is to determine what exactly Plutarch wishes to celebrate regarding his country; the glorious days of its political liberation, perhaps. But not only that: no less important is the criticism that Plutarch wishes to oppose from the very beginning of the dialogue, namely the charge of misology - a charge that was habitually directed against the Boeotians (575e). Some scholars have dismissed this point as irrelevant. ${ }^{19}$ But this is not correct. As Rudolf Hirzel demonstrated long ago, the De genio Socratis is deeply influenced by Plato's Phaedo; indeed, the structural parallels are so strong that it can be read as a rewriting of the Phaedo. ${ }^{20}$ Among other parallels, also in this specific case it is easy to detect a reference to an important page of Plato's dialogue, where it is argued that the rejection of logoi amounts to a rejection of philosophy: ${ }^{21}$ in other words, what is at stake with misology are not 'cocktail party talks' but philosophy, whose importance for Plutarch need not be underlined. As has been correctly remarked, one aim of the dialogue is to defend the philosophical competence of the Boeotian

\footnotetext{
17 See Christ 1901, 61; Latzarus 1920, 36; more recently Vernière 1977, 93.

18 As it turns out, it should also be observed that nowhere in the dialogue the reader can find an uncontroversial celebration of this political episode. In particular, it is remarkable that in the prologue (whose importance will be discussed below) Plutarch invites the reader to pay attention to the characters, that is to virtues, more than outcomes; equally important is the passage in which Plato claims that God invites the Greeks to study philosophy and not to fight one another ( $579 \mathrm{~b}-\mathrm{d})$, which is precisely what happens in the dialogue where the conflict between Athens, Thebes and Sparta is constantly alluded to. Writing centuries after the revolt, he was well aware that it did not result in an epoch-making episode: Theban hegemony lasted only ten years - not a long time compared to Roman hegemony, whose importance Plutarch is ready to underline by claiming that it was favoured by divine providence, see Brenk 2002, 105-110 and (on Rome) also Swain 1989, 286-292. Clearly, Plutarch's patriotism did not amount to chauvinism.

19 Corlu 1970, 87-89.

20 See Hirzel 1895, vol. 2, 148-150, 162 n. 5; see also Corlu 1970, 86.

21 Cf. Phd. 89c with Dorion 1993 and Wolf 2007.
} 
patriots, who are presented as capable not only of acting but also of participating in philosophical discussions. ${ }^{22}$ If this is the aim, it is evident that logoi must occupy an important place in the economy of the dialogue.

One scholar who has greatly contributed to a better understanding of this text in recent times is Daniel Babut. By rightly insisting on the importance of logoi, Babut has also highlighted the central role played by the 'philosopher' Epameinondas. ${ }^{23}$ According to his interpretation the main theme of the dialogue is a celebration of the theôrêtikos bios, the life most distinctive of the philosopher, who is embodied by the character Epameinondas, 'the Boeotian Socrates'.24 Many other readers agree on the pivotal role of Epameinondas, the only major character who is involved not only in the discussions but also in the political action (see below). ${ }^{25} \mathrm{He}$ is always a point of reference for both the discussants and the rebels, and thus clearly occupies a strategical position in the text. ${ }^{26}$ Moreover, it is also clear that in the dialogue Epameinondas appears as a philosopher $(576 \mathrm{~d}, 585 \mathrm{~d})$; even better, he is depicted as an Academic (i.e. Platonic) philosopher. ${ }^{27}$

But what about Babut's claim that the main theme of the dialogue is the celebration of the theôrêtikos bios? This is hardly convincing, for there is a risk of going to the opposite extreme of the above-mentioned reading of the liberation of Thebes as the only important theme. The importance of logoi cannot be denied, but this does not justify the hypothesis that logoi are the only relevant theme, and that political events can therefore be dismissed as a mere framework to a dialogue devoted to the celebration of the detached philosopher. This interpretation goes too far, and is not supported by a careful reading of the text. It is true that some characters criticize Epameinondas in the dialogue precisely for his refusal to commit himself to political action $(576 \mathrm{e}),{ }^{28}$ but other characters clearly show that this is a misrepresentation of his intentions (576e-577a; see also 585d, 594c). Epameinondas does not directly take part in the 'putsch', but he is however involved in the conspiracy (594a-b; see the final

See Ziegler 1964, 204; Stoike 1975, 236, and Georgiadou 1995, 191-192 with the list of passages in note 13 (to which one can add De Herodt. mal. 864d). If we wish to speak of Plutarch's patriotism, we should speak of 'philosophical patriotism', in this text at least.

23 Babut 1984, $56-58$ et passim.

24 As he was defined by Kahle 1912, 85 and 93 .

25 Also Theocritus and Galaxiodorus intervene in both the action and the conversation, but with minor roles, cf. Donini 2011, 404.

26 See Corlu 1970, 19; Hershbell 1988, 365-381; Barigazzi 1994, 214-220.

27 Cf. Donini 2011, 406-410 and 2017, 22-31; this was alread adumbrated by Hirzel's distinction of Pythagoric and Socratic elements as constitutive of philosophy: Hirzel 1895, vol. 2, 162. On the virtual identification of 'Academic' and 'Platonic' in Plutarch, see Bonazzi 2012a.

See also Pel. 5.4. 
section $594 \mathrm{a}-598 \mathrm{f}) \cdot{ }^{29} \mathrm{He}$ is as concerned with Thebes' fate as the conspirators are. He cannot then be regarded as the champion of a retired life, dedicated to pure contemplation, for he is not as detached as Babut claims. As a matter of fact, in the dialogue even Socrates, Epameinondas' philosophical model, does not only engage in contemplation, but combines theoria and praxis: he is interested in typically metaphysical problems such as demonology $(588 \mathrm{c}$, $592 \mathrm{~d}-\mathrm{f}$ ), but he is also ready to take care of his fellow-citizens (581d-e). A reading of Epameinondas as a pure contemplative cannot correctly account for the complexity of this character.

Incidentally, such an interpretation fits Plutarch's general views, as they emerge from his other writings. As scholars have shown, what is distinctive of Plutarch is his defence of the philosophical life, which combines both theôria and praxis. ${ }^{30}$ This proves to be incompatible with Babut's interpretation of the De genio. An excellent reader of Plutarch, Babut was himself aware of the difficulty and concluded his paper by acknowledging the existence of 'diverging tendencies' in Plutarch, which cannot be properly reconciled. A more coherent interpretation of Plutarch can be formulated, if in relation to the De genio one takes into due account the parallel importance of both logoi and praxeis, and their close connection, as it emerges from the character of Epameinondas.

More precisely, the problem is how to reconcile the need for a union between theôria and praxis on the one hand, and the character of Epameinondas on the other. For Plutarch, as we have seen, philosophy (and the philosophos bios) consists in the union between theôria and praxis; Epameinondas is described and appreciated as a (Platonic) philosopher, both here $(576 \mathrm{~d}, 585 \mathrm{~d})$ and also elsewhere in the Plutarchean corpus. ${ }^{31} \mathrm{He}$ is one of Plutarch's philosophical heroes. Consequently, the problem is: how is it possible to account for the fact that Epameinondas is both contemplative and actively, politically engaged? The difficulty, of course, does not concern so much the theoretical/ contemplative aspect as the active side. In what sense can we take him to be active too? In order to answer this question, we must first make it clear what

29 Cf. the parallel of Pel. 7 and 12. Interestingly, it has been observed that a comparison with other historical testimonies (Xenophon or Cornelius Nepos) suggests that Plutarch overemphasized Epameinodas' role in the revolt, cf. Barigazzi 1994, 229.

3o I refer the reader to Bonazzi 2012b. Among the most relevant texts, see Prof. virt. 84b; Stoic. rep. 1033a-c, Adv. Col. 1127a, 1127e.

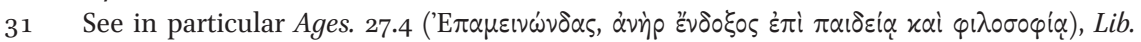

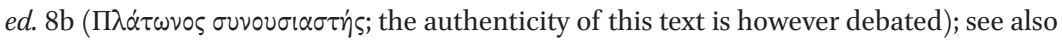
Arist. 1.3, Quom. ad. 52f, Prof. virt. 85a-b, Tranq. an. 467e and 472d, Cup. div. 527b, Lat. Viv. $1129 \mathrm{~b}-\mathrm{c}$ (Epameinondas and Plato or Socrates associated). 
'active' means for Plutarch. And to do so we must get back to the problem of the philosophical life.

\section{$3 \quad$ Plutarch on Philosophy and Politics}

As a thinker, Plutarch has rarely received good press in modern times. The praise of the man and of the writer is unanimous and ubiquitous, but the philosopher is often reproached for being either incoherent or banal. Babut's final judgment on Plutarch's oscillations is a sign of this trend, and further examples can be adduced, especially when we focus on his political views. Like many other writers of his time Plutarch presents the philosopher as the ruler's adviser. This has raised accusations of inconsistency or banality. On the one hand, it seems doubtful that this idea can be combined with the earlier Platonic model of the philosopher-king; on the other, the model of the philosopher-adviser was a standard model in Hellenistic reigns and even more in the Roman Empire. ${ }^{32}$ Is there any political thinker in the Imperial centuries who did not recommend this model?

In fact, Plutarch is neither inconsistent nor banal. He is not inconsistent, because the two models, the philosopher-king and the philosopher-adviser, are both compatible with a Platonic framework, especially if one takes into account Plato's own life and his travels to Syracuse, as reconstructed in the Seventh Epistle (which the ancients regarded as authentic). That one must avoid philosophizing in vacuo, without taking due account of external conditions, is not only Plutarch's conviction but something that Plato himself would have approved of, as Plutarch claims by referring to the Seventh Epistle: 'Plato, as he tells us himself, out of shame more than anything else, lest men should think him nothing but theory and unwilling to take any action ... yielded' and travelled for the second time to Syracuse in order to advise Dionysius. ${ }^{33}$ The ideal probably remained that of the philosopher who rules directly, but this was hardly an applicable model at the time. ${ }^{34}$ The alternative option of the philosopher adviser was a perfectly legitimate (that is Platonic) option.

\footnotetext{
32 See for instance Jones 1971, 117; Carrière 1984, 36-40 and 51-53; de Blois 1999, 303-304.

33 Vit. Dion. 11.3, the reference is to Ep. 7, 328c; see also Max. cum princ. $779 \mathrm{~b}$-c: 'the teachings of philosophers, if they are firmly engraved in the souls of rulers and statesmen and control them, acquire force of laws; and that is why Plato sailed to Sicily, in the hope that his teachings would produce laws and actions in the government of Dionysius.'

34 Plutarch adopts Plato's theory of the philosopher-king as a political ideal more apt for the past than for the present days of the Empire, cf. Num. 20.8-9; Lyc. 31.2; see also comp. Dem. et Cic. 3.4; see Aalders 1982, 41.
} 
Plutarch is not banal, because the adoption of the standard model of the philosopher adviser allows him to advance ideas which are not trivial. And this for two main reasons at least. First of all, as Michael Trapp has brilliantly shown, what Plutarch sets out to achieve is a "philosophization of politics". ${ }^{35}$ By introducing a standard theme Plutarch advances proposals which contrast with and try to reverse many current values in a subtle way. An interesting example are the polemics against euergetism, honours and the dedication of statues, three strictly related and central issues in the life of civic communities under the Roman Empire. Plutarch talks of euergesia and appears to approve of philotimia, but then qualifies these values in ways which are not easy to reconcile with mainstream civic practices. True euergetism does not consist in public donations or in paying for theatrical shows or gladiatorial spectacles (Praec. 821f), but rather in concern for the well-being of one's fellow citizens (Praec. 822d-823b); true honour lies in the people's grateful awareness of the politician's goodwill and benevolence, not in the display of power and richness (Praec. 820f). ${ }^{36}$ That is why the genuine politician should not accept the dedication of statues - one of the most common expressions of power at the time (Praec. 819f-82oc, 798c, 799a). The aim is clear and far from banal. Plutarch tries to make the world of everyday politics depend on the norms suggested by philosophical reasoning. Real politics cannot be reduced to the quest for power and honour. The opposite is rather the case: real politics has to do with living well (An seni $783 \mathrm{c}$ ) and living well ultimately depends on virtue. Philosophy and politics, in other words, tend to coincide; but if they coincide, it is because "politics is tantamount to moral education": it is because the task of the real politician is "to take care of his subjects, and the best way to do this consists in leading them towards moral virtue". ${ }^{37}$ This implies that real politics is somehow subordinated to philosophy. ${ }^{38}$

Moreover, and this is the second main reason, it is not only a matter of a "collapsing of administration into ethics". ${ }^{39}$ What is really intriguing and distinctive about Plutarch's political treatises is the metaphysical apparatus which supports his political thought and which leads to the original claim that

35 Trapp 2004, 198.

36 On philotimia, see Pelling 1989, 208-213 and the papers collected in Roskam, de Pourcq, and Van der Stockt 2012.

37 Roskam 2002, 177 and 181.

38 Trapp 2004, 193, who quotes An seni 796c-d. Further confirmation comes from the praise of Lycurgus, the king who regarded paideia as the most important task for the legislator (Lyc. 14.1), and succeeded in turning Sparta into a polis philosophousa (Lyc. 31.3). It is philosophy which made him a great politician.

Trapp 2004, 198. 
between the ruler and the philosopher-adviser it is the latter who is superior: while politics is subordinated to moral education, moral education is founded in metaphysics. I am referring to one distinctive doctrine of imperial Platonism, repeatedly emphasized by Plutarch, the doctrine according to which our end $(\tau \dot{\varepsilon} \lambda \circ \varsigma)$ is to assimilate ourselves to God ( $\left.\delta \mu o^{\prime} \omega \sigma \iota \varsigma \tau \hat{\omega} \theta \varepsilon \hat{\omega}\right) .{ }^{40}$ In other words, the ethical consistency that we create in our soul is the imitation of the order of the universe produced by God. Just as God attains perfect virtue by engendering order, harmony and justice in the universe, so we can achieve our telos by successfully recreating order and harmony in our soul and in human society. ${ }^{41}$

In society the philosopher distinguishes himself by his ethical consistency. But his real interest, and the proper foundation of his virtue, is the divine realm. It is this interest which informs his actions and advice. He is not the prudent counsellor of the specula principis tradition, but rather the mediator between the divine and the human world. It is in consequence of his mediating function, a function that somehow assimilates him to the daemons, that Plutarch can argue in favour of the philosopher's superiority. If the most important task of the politician is to recreate the order of the universe in the human soul and the social world, ${ }^{42}$ the importance of the philosopher-adviser, who has a better acquaintance with God and is more capable of understanding this divine order, becomes clear. ${ }^{43}$ In other words, politics, ethics and metaphysics are reconciled: the proper objects of contemplation are the divine realities which, once properly grasped, necessarily foster a deep transformation of oneself (i.e. of one's own soul) which, in turn, inevitably bears practical (ethical but

\footnotetext{
$40 \quad$ For a detailed account, see Bonazzi 2012b, 150-153.

41 See Sera num. vind. 55od-f.

42 Ad princ. in. $780 \mathrm{~d}-\mathrm{f} ; 78 \mathrm{1a} ; 78 \mathrm{ff}-782 \mathrm{a}$; Praec. 823f; cf. also what the Roman aristocrats say to Numa in Num. 6.2; fr. 28.

43 See Dio 10.1-3, where Plato, the philosopher par excellence, is the guide who helps the ruler to become virtuous (especially righteous), i.e. to strive towards the deity as far as possible, engendering in him that order and harmony which serves as the foundations of collective and individual happiness. Another interesting passage is Per. 16.6-7 (cf. also 4.4-6.4), where Anaxagoras is mentioned. Anaxagoras was traditionally regarded as the typical contemplative philosopher (Arist. EN 6.7, 1141b). For this reason Babut 1984, 72-74 exploited this text as confirmation of his 'contemplative' interpretation of Plutarch. Plutarch, however, presents the pre-Socratic philosopher as a 'counsellor in the conduct

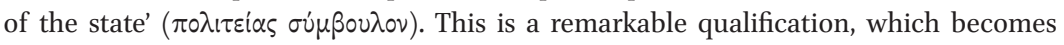
even more remarkable when one detects in the passage a probable reference to Pl. Phdr. 270a, where Anaxagoras is (ironically) exalted as the adviser who mostly contributed to Pericles' success thanks to his adoleschia and meteorologia - which amount not to 'party dinner conversations' or fruitless speculations but to philosophy.
} 
also political) consequences. A life devoted to such an enterprise is a life devoted to philosophy. ${ }^{44}$

One may think that this is wishful thinking or "piously unrealistic":45 we will come back to this point later. But at least it should be admitted that Plutarch's ideas are much more well-articulated and much less banal and incoherent than scholars tend to assume. And it is only if we understand these ideas that the enigmas of the De genio Socratis can be solved.

\section{4 \\ Vita activa and vita contemplativa in the De genio Socratis}

If we take all this into due account, a possible solution to the riddle of the De genio Socratis emerges. Epameinondas is a philosopher and can coherently be regarded both as the centre of the dialogue and a supporter of the philosophical life precisely in the above-sketched sense. Admittedly, Plutarch is reticent and presents Epameinondas "in an unconnected and unsystematic manner". ${ }^{46}$ But all the necessary elements for a correct interpretation are present in the text, and it is the task of the careful reader to put them together. First of all, there is the fundamental question of ethics, for we have seen how politics cannot be reduced to the mere administration of power, since it has virtue as its main target. This is Epameinondas' priority: his virtue is underlined in the dialogue by other characters $(585 \mathrm{~d})$, and it strategically appears in his apology of poverty $(583 \mathrm{~d}-585 \mathrm{~d})$, which also serves to stress his proximity to Socrates (581c).

In addition, strange as it may appear at first sight, the discussion on poverty also serves to account for Epameinondas' daemonic nature. For, as Epameinondas explains to Theanor, the rejection of money is part of a process of askêsis the final purpose of which is purification from passions: and purification from passions is the condition which enables souls to get directly in touch with the divine world of the daemons, ${ }^{47}$ as is explained in the discussion on Socrates' daimon (588d-589e) and as will be shown in Timarchus' myth: the more one is free from passions and desires ( $\kappa \alpha \theta \alpha \rho \dot{\rho} \varsigma, \dot{\alpha} \pi \alpha \theta \dot{\eta} \varsigma$ ), the more genuine his contact with the daimones is (588d-e). ${ }^{48}$ This clearly holds in the case of Epameinondas, whose perfect virtue is never contested and whose

44 Incidentally, this is a perfectly legitimate reading of Plato: see for instance Nightingale 1995, 60-92 and Neschke-Hentske 1995, 207-216.

45 Trapp 2004, 195 and 197.

46 Georgiadou 1996, 118.

47 More generally, see Babut 1984, 57.

48 On this point see Riley 1977, 267-268 and Babut 1984, 58. 
daemonic nature is repeatedly underlined. Particularly important, in this regard, is the comment of the Pythagorean Theanor, which occurs in a strategic position, just after Epameinondas' speech on poverty and freedom from passions and immediately before the explanation that Socrates' link with the daemon is granted by his pure mind ( $586 \mathrm{a}$; see also $593 \mathrm{~d}$ ). Both Epameinondas' ethical perfection and its metaphysical dimension are therefore confirmed.

Once this is grasped, it remains to be considered whether the ethical and divine aspects of his character also imply some sort of 'political' commitment. The answer, if we pay due attention to what Plutarch understands by political commitment, is positive. Again, the speech on poverty provides a first, if small, example of this engagement, for the discourse contains many points which question the social value commonly assigned to money. A comparison with the De cupiditate divitiarum and the De vitando aere alieno would prove very fruitful in this regard. Epameinondas' engagement emerges more in general also with regard to the Theban affair, once it becomes clear that his engagement does not coincide with what the other characters (or the readers) expect. The exchange with the seer Theocritus is the most important passage. Theocritus reproaches Epameinondas for his decision not to take part in the action ('not to help men who are braving danger for their country', 576d). But the reason for this is not, as Babut claimed, that Epameinondas is a detached philosopher, lost in theological visions. Rather, his main purpose is to obtain something that this action (with the many passions it involves: see $577 \mathrm{a}$ and the episode narrated at 597b-c) might fail to achieve: his aim is to promote justice and the common good, harmony and peace $(576 f-577 a)$. It is in this sense that Epameinondas is active.

A difficulty remains, however, for it might be objected that this passage confirms Epameinondas' commitment but not the fact that his engagement is theologically grounded. It may be objected that, on the one hand, we have Epameinondas' ethical concerns, which prompt him to act for the sake of justice, and, on the other, the ideal of the divine man that he embodies. The idea that these two elements can and must be reconciled is supported by a close reading of the dialogue in its entirety. For, as we have seen, moral perfection entails direct contact with the daemons and it is clearly said that these creatures take care of human beings and try to help them, albeit not in the way human beings think they do- that is, daemons help men not to win wars, but to purify their souls and live peacefully and virtuously. And this, we have seen, is real politics for Plutarch.

Once again, it is remarkable that this also clearly appears to be the case with Socrates. The link that keeps together Socrates' ethical perfection and his daemonic nature is evident, and it is also explicitly affirmed that his political 
commitment (taking care of others) depends on the daemonic sign (581d): ethical perfection is the precondition for getting in touch with the daemon and the daemon's exhortations are political — not in the standard sense, but in the sense that they lead Socrates to take care of others. Given the emphatic parallel between Epameinondas and Socrates, one can infer that the same also holds in the case of the latter. Socrates' 'political' engagement is daemonic.

\section{5}

\section{Plutarch and His Readers, Epameinondas and Plato}

A most important confirmation of this reading comes from a passage of the text whose importance can only be grasped if we pay due attention to Plutarch's communicative strategies. As has been observed, the De genio Socratis is about signs (Socrates' daimonion is more precisely Socrates' daemonic sign), and it is a remarkable feature of the dialogue that signs occur throughout without any clear indication of how to interpret them. ${ }^{49}$ This is typical of Plutarch, who is less willing to impose his views on the reader than usually assumed. It implies a second, equally important, characteristic, namely the need for interpretation, which reveals the 'adequate' reader, ${ }^{50}$ the reader who has proved himself able to meet Plutarch's challenge by reading the text with proper philosophical attention. ${ }^{51}$ In a world of signs, there is no dearth of clues which can lead us to solve 'the problêma of Epameinondas', as this is progressively disclosed over the course of the text. Not only is the dialogue dotted with signs in need of interpretation, but from the very beginning of the text we are also shown how to proceed if we wish to make sense of them: unlike the 'duller minds' who are content with 'the general drift', we must pay attention to 'each detail'; like 'the spectator fired with emulation and the love of noble conduct', we must be delighted with the 'particulars' ( $575 \mathrm{~b}$-d). It is attention to such details, even if they do not appear to be a relevant part of the story, and the capacity to put them together (by detecting the relevant ones) that distinguishes the competent interpreter from the incompetent, who like Hipposthenidas is concerned only with $\mu \varepsilon \gamma \alpha \dot{\alpha} \lambda \alpha \sigma \eta \mu \varepsilon \hat{\alpha} \alpha$ (586f) and fails to understand what is happening.

If this is so, it is remarkable that Plato himself is introduced into the text in an apparently insignificant way. When the people of Delos seek his counsel on a 'strange response from the god' that pledged to put an end to their woes,

49 Hardie 1996, 124: "There is scarcely a page of the work that is not concerned, in one way or another, with signs and their interpretation."

50 Hardie 1996, 135 .

51 See König 2007. 
on condition that an altar be built at Delos twice the size of the existing one, Plato construes the response as an exhortation to study geometry in earnest and explains the importance of the median point between two extremes, going on to say that 'they were not, however, to suppose that it was this the god desired, but rather that he was ordering the entire Greek nation to give up war and its miseries and cultivate the Muses, and by calming their passions through the practice of discussion and study of mathematics, so to live with one another that their intercourse should be not injurious, but profitable.' (579c-d) Plato's exhortation in the text is not isolated but follows the similar exhortation of the Egyptian god, who 'instructed and urged the Greeks to live in the enjoyment of leisure and peace by always taking philosophy as their field of contention, laying their arms aside and settling their dispute about right and wrong by an appeal to the Muses and discussion.' (579a) These two texts, occurring at the beginning of the dialogue, may strike the reader as simple anecdotes. But as the main themes of the dialogue progressively emerge, can we really affirm that the reference to Plato (and to the Egyptians) interpreting a message (another sign!) of the god, a message which other humans being were not able to decipher, is unimportant? This is a double message, which explicitly associates peace and justice, war and passions, with philosophy and the gods. At first sight this may appear as an unimportant anecdote. But to the 'adequate reader' it appears as the key to understand the deep meaning of Epameinondas and disclose the focal theme of the dialogue. As it turns out, Epameinondas is the only character in the text who tries to do what Plato and

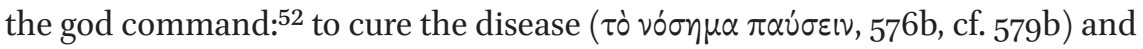

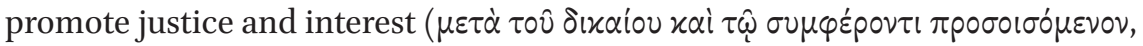

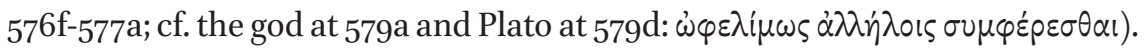
Like Plato in the anecdote, the last time we meet Epameinondas, at the conclusion of the dialogue, he is in front of the temple of Athens (598c-d): this image vividly describes Epameinondas' engagement, as we have reconstructed it. The parallel between Plato, Socrates and Epameinondas is not casual: it is rather by comparing these three figures that we can grasp the unity of the dialogue and its main theme, which is the celebration of the philosophical life in a world dominated by passions. ${ }^{53}$

$5^{2} \quad$ See also Donini 2007, 112-113.

53 Needless to say, the parallel does not imply that Epameinondas must be regarded as the perfect equivalent of Socrates and Plato, cf. Riley 1977, 270-271; Georgiadou 1996, 121; Donini 2011, 418 and 2017, 17-30, 195 et passim. Still, the fact remains that Epameinondas, like the other two, is pure and in contact with the divine world; like the other two he is a philosopher and a representative of the philosophical life: see Barigazzi 1994, 226. 


\section{A Unitary Reading of the De genio Socratis and a Vindication of Philosophy}

The unity of the De genio Socratis is therefore confirmed, and its many, and seemingly divergent, parts can finally be put together. As many scholars have repeatedly showed, the dialogue is built on the strong correspondence between the plane of historical (ethical and political) events and that of demonological and mythical discussions. The historical and the theological levels correspond to each other as the two sides of the same coin; they are two discourses mirroring the same reality. Each section reflects the other, so that "the unity of the tractate becomes highly visible in this interplay"54 and Plutarch's position can be appreciated for his philosophical coherence. Actions are produced by characters and characters can be described both in ethical and metaphysical terms. To be more precise, the description of the different characters involved in the action is paralleled by the metaphysical discussion of the souls and their connection to the daemons. Whereas the narrative sections portray what appears in the 'real' world by describing the physical actions and psychological motivations of the characters, the philosophical discussions, together with the mythical section (that we do not have space to investigate here), reveal the spiritual bases of those actions by showing what happens to our souls in the grand theatre of the universe. ${ }^{55}$ And whereas the historical narrative is tortuously elusive, the myth offers a kind of 'view from above' and provides a pattern to decode what happens. In both cases we see different degrees of entanglements of the souls with their bodies: and the more one's soul will be immersed into the body the more it will be enslaved to its passions, losing the daemons' guidance and failing in its choices and actions (591d-592c). The confused movements seen by Timarchus vividly describe the confused lives which are narrated in the dialogue between Caphisias and Archedamus. On the other extreme there are those who are called 'inspired men' (592c), pure and free from passions, and therefore able to listen to their daemonic guides. ${ }^{56}$

It is within this grandiose two-level description of human activity that the importance of philosophy - as represented by Epameinondas in the footsteps of Socrates and the divine Plato ${ }^{57}$ — can properly be grasped. What distinguishes

\footnotetext{
54 Stoike 1975, 238; Desideri 1984, 578; Brenk 1996, 41.

55 Riley 1977, 272; see also Deuse 2010, 170.

56 See Brenk 1996, 41: "From the philosophical point of view, the account of the conspiracy has less importance ... In spite of its 15 pages, the historical 'narrative' primarily seems to be an illustration either of daimonic intervention and control in the world, or of the juxtaposition of supernatural and natural worlds." See also Brenk 2002, 110.

Cap. ex. in. 9oc; Per. 8.2. See Riley 1977, 269-270; Desideri 1984, 583 .
} 
the philosopher from all other human beings is the virtuous control of his rational part over passions (588f-589c); from a higher metaphysical perspective, this corresponds to a closer relationship with his own daemons and confirms the superiority of the philosopher. For, to put it briefly, the demonological discussions serve to show that the rational part corresponds to what is divine in us: ${ }^{58}$ whereas other men are (to different degrees) dominated by the irrational part of the soul, which drags them down into the world of disorder (as is shown in the narrative section by Eumolpidas and Samidas, 577a, or even worse by Archias, who is so sunk in the pleasure of the body that he cannot even read a letter, 596e), the philosopher, insofar as he is 'free from passions', can properly listen to the divine voice within him (the daemonic sign) and act accordingly, that is by taking care of the souls of his fellow-citizens and friends.

The philosopher is the true daemonic leader of men, above and beyond the juxtaposition between contemplative thinkers and political men. On the strength of his privileged relationship with the divinity, the philosopher must seek to promote the values of the divine world among men, not stooping to their lowly political wrangling, but facilitating their heaven-bound ascent; his duty is to help them rise to the blissful state he has already attained alongside God. This is his task: to help others become virtuous-which means helping them unite with the divine part within themselves. And this lays the foundation for a world and a social order based on and in harmony with divine justicewhich means bringing mankind and the universe together. If the debate on the bios philosophos is also a vindication of philosophy, one cannot help but notice that the perspective put forward by Plutarch amounts to a grand celebration of philosophy, which proudly reasserts its practical and political significance at a historical time in which room for action was shrinking fast.

\section{The Failure of Philosophy}

Of course, I am aware that there is a substantial objection to this interpretation and to Plutarch's views, if my reading is correct. Let it be conceded that Epameinondas is the centre of the dialogue because he is the best representative of the philosophical life: always contemplating the divine order which regulates the life of the universe, he takes care of the souls of his fellow citizens and tries to order them according to this divine order.

$5^{8} \quad$ For a detailed analysis of Plutarch's demonology in the De genio Socratis, see now Timotin 2012, 244-259. 
He tries. But in fact he fails: Plutarch states that Epameinondas cannot persuade others ( $576 \mathrm{f}$, twice: 'Epaminondas has been unsuccessful in his endeavour to persuade us to drop them, as he believes would be for us the best'; 'but since he does not persuade the majority, and we are already engaged in this

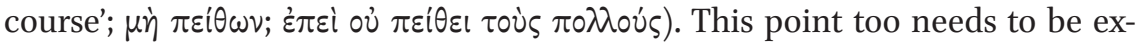
plained. Does this not mean that the dialogue is not so much a celebration of the philosophical life as an acknowledgment of its failure? The question is legitimate, yet I do not take it as a critique of the above interpretation, but as a decisive qualification of the philosophical life. In order to understand this last point, we must get back once again to the parallel with Plato. So far I have repeatedly alluded to and insisted on the importance of Plato. Now, it is fundamental to recall that also the problem of the limits of effectiveness is a typical problem of Plato and Platonism. Also from this perspective it is the parallel with Plato that helps us interpret Plutarch's texts.

Needless to say, this is not the occasion to dwell on a well-known aspect of Plato's philosophy that is underlined in some unforgettable pages of his dialogues: suffice to recall the end of the discussion between Socrates and Callicles $(\mathrm{Grg} .513 \mathrm{c}$, where Callicles concludes by saying: 'somehow or other I think you're speaking well, Socrates. But the same thing happens to me as to most people; I'm not quite convinced by you'-ov $\pi \varepsilon(\theta \circ \mu \alpha \mathrm{l})$, not to mention the destiny awaiting the philosopher who returns to the cave $(R .517 \mathrm{a})$. Developed as a response to Socrates' death, the dialogues constantly evoke the possibility that philosophy might fail.

This is well known to the modern reader, and to Plutarch too. Also from this perspective, therefore, Epameinondas is connected to his models, Plato and Socrates, as becomes clear when we consider how both figures are presented in the dialogue, as well as Plutarch's intertextual choices. As regards the short reference to Plato, it is interesting to remark that he emerges as a sort of prophet speaking for the sake of the God (he said that 'the god was ordering ...', 579d). But, as is often the case with prophets, it seems that no one is following his exhortations: there is no 'end to the present troubles of the Delians and the rest of the Greeks' (579b). ${ }^{59}$ The dialogue occurs in the middle of a civil strife involving the most important Greek poleis (Thebes, Athens, and Sparta); but no end to these troubles is in sight.

The situation is not different with Socrates. In the De genio and elsewhere in Plutarch's texts, Socrates is the ideal philosopher, who can best combine 
theôria and praxis. But this does not imply that he is successful in his efforts. ${ }^{60}$ His divine inspiration, which he, more than anyone else, enjoyed, rescued him on many occasions, both trivial and serious: they saved him from getting dirty when a horde of pigs was running amok (58od-f), but also saved his life during the retreat from Delium (581d; note that the Delium episode is part of a war between Athens and Thebes, that is the two cities represented by the speakers in the dialogue). But providential as it is, his divine signs did not save others: Socrates was not able to persuade his friends not to take the road infested by the horde of pigs; neither did he convince many of his fellow-soldiers to follow him during the retreat from Delium. And it is not a matter only of Socrates' companions: his daemonic sign allowed him to foresee the Sicilian disaster (581d), and we all know what happened. ${ }^{61}$

The importance of these 'details' is further confirmed when we take into consideration one of the texts which constitute Plutarch's subtext. Scholars have often remarked that the list of episodes with Socrates and divine signs can be read as a clear allusion to the Theages. ${ }^{62}$ At least the reference to the Sicilian expedition counts as an explicit quotation of the dialogue, whose last section enumerates a list of episodes in which someone, be it a friend of Socrates' or an Athenian citizen, did not listen to Socrates' daemon and met a fatal end (Thg. 128d-129d): 'to many the intercourse with me does no good' (Thg. 129e). The references to Socrates' deeds and thoughts depend on passages of Plato's dialogues which reflect the same awareness of the limits of philosophy. Incidentally, if we recall that the De genio can properly be read as a rewriting of the Phaedo, we can easily understand that the parallel with the dialogue dedicated to the last day of Socrates, as he awaits his execution in jail, is not casual, but implies the same awareness of the limits of philosophy in a world dominated by passions. ${ }^{63}$

6o On the problematic presentation of Socrates in the De genio Socratis, see Pelling 2005, 125-134.

61 Another interesting parallel is Simmias, who does not persuade Leontiades to spare the life of Amphitheüs, see $577 \mathrm{~d}, 578 \mathrm{c}$.

62 Cf. Georgiadou 1996, 196. From the Lamprias Catalogue ( $\left.C L{ }_{71}\right)$ we know that Plutarch argued in favour of the authenticity of the dialogue.

63 Many other texts confirm Plutarch's awareness of the limits of philosophy. Another two philosophical heroes of Plutarch's are Brutus and Dion, the best products of the Academy (Dio 1.4). But it is not so clear whether they were really successful, judging from their lives: "if this is the route to Plato's Republic, it has certainly taken some odd diversion along the way" (Pelling 2004, 93). The parallel with Dion, who at some point takes the wrong decision for the want of showing his philosophical expertise (cf. Vit. Dion. 52-53 with Pelling 2004, 91-97 and Bonazzi 2012b, 160-161), might also lead to an alternative interpretation of Epameinondas' 'failure'- that Epameinondas was not right, after all, because that was 
This is the way human things go, and Plutarch's 'philosophy of history' turns out to be less optimistic than one might guess. ${ }^{64}$ There are the glorious days of the Theban revolt, but there is also the awareness that human history is not as reasonable as one would like it to be; unfortunately, also passions play a great role, nor should one underestimate the presence of tyche. And this ultimately leaves the philosopher-be it Socrates, Epameinondas or Plutarch-in an ambiguous position. Halfway between the world of men and that of the gods, a witness to a different way of understanding life, withdrawn (in silence: $592 \mathrm{f}$ ) into a sort of limbo, at peace $(583 \mathrm{c})$ thanks to the harmony he has reached, but perhaps also concerned about the disarray in which others live. The parallel with the daemons is clear and it is not by accident that the philosopher is presented as a daemonic man. But the problem is that the daemonic time of philosophy, as it is depicted in the myth, is not always capable of

the time for a violent action, as Pelling 2010, 125-126, has suggested. It should however be remarked that the two texts, in spite of all their similarities, do not perfectly coincide. In Dion's case it is matter of how to apply philosophical doctrines or arguments in concrete situations; in Epameinondas' case, given his virtual identification with the (superior) models of Plato and Socrates (cf. Georgiadou 1996), it is rather a matter of reflection over philosophy's (limited) effectiveness more in general. In both cases it is interesting to remark that Plutarch emerges as a much less unequivocal thinker than he is usually taken to be. More in general on Plutarch's evaluation of the political violence in the De genio Socratis, see now Donini 2017, 38-46.

64 A different view is defended by Desideri 1984. He has correctly presented the De genio as a sort of drama on two, strictly interconnected levels: the world of humain affairs is dependent upon a higher metaphysical order. This is certainly correct, but it is highly questionable that the metaphysical level, the world of daemones, directly "controls" (Desideri $1984,579)$ all the human actions down to the smallest episode, assigning victory to one side against another; and it is even more questionable that this occurs thanks to the mediation of Epameinondas, "the man in direct contact with gods", the "moral guarantor" (p. 583). The relevance of fate should not be so easily dismissed $(575 \mathrm{C})$ and it is not correct to say that the daemons "did take part in the revolt", or that they "controlled the development of the events" (p. 581), willing to help the followers of Epameinondas (p. 583), as correctly remarked also by Swain 1989, 286. True, the revolt was successful and the conspirators were morally better than their adversaries. But they were not entirely free from passions and perfectly rational. Their interest cannot be regarded as being identical with Epameinondas' motives - even less, those of the daemons. Once again, it is the doctrine of the soul that helps us here. If we adopt the tripartition of Plato's Republic, we can admit that their courage reveals a thymoeidetic character which is by far superior to the epithymetic passions of their adversaries; but they are also below the rational purity which is distinctive of the philosopher: see Timotin 2012, $25^{8}$ and Donini 2017, 21. Pace Stoike 1975, 242-244 and Desideri 1984, 581, the liberation of Thebes is not the same as the liberation of souls. 
effectively fitting in with the time of history. ${ }^{65}$ This, too, is part of the Platonic and Socratic legacy.

\section{$8 \quad$ Concluding Remarks}

If my reconstruction is correct, there is a 'spectre haunting' the pages of $D e$ genio and of many other Plutarchean texts. This is the spectre of Plato, who in the early Imperial centuries was an object of passionate debate. In this period almost all schools (with the exception of the Epicureans) tried to absorb Plato within their own philosophical systems, to the effect that many different and often mutually incompatible 'images' of Plato started circulating. Against all other schools, Plutarch argued for Plato's superiority and priority; against many of his Platonist colleagues he insisted on the social utility of his thought (from Antiochus to Alcinous the emphasis had rather been on theôria). In short, one can present Plutarch's interpretation of Plato, and hence the philosophy put forward by Plutarch himself (who styles himself as nothing else but a faithful interpreter of Platonic philosophy), as an attempt to show that Plato's supremacy is confirmed by his social impact.

But at the same time, Plutarch was too careful a reader of Plato not to see that the latter's philosophy was difficult to reconcile with the values of his own age (just as it had been difficult to reconcile with the values of the $5^{\text {th }}$ and 4th centuries BC): one could propose (ethical) reforms, but it was almost impossible to transform the world into the kallipolis, as Plato himself finally acknowledged in the Laws. A faithful reader of Plato, Plutarch did not avoid this problem, facing the risk of failure. Scholars often dismiss Plutarch by accusing him of incoherence. But incoherence and oscillations, when they occur, do not concern his philosophical thought. They rather concern the contrast between philosophy and society. This is the problem for Plutarch as much as for Plato, the philosopher who had invented philosophy in order to 'save the city' but then ended up hiding the philosopher behind a teichion $(R .496 \mathrm{~d} 7)$. Surely Plutarch's loyalty to Plato constituted a major obstacle in the social game he was 'cleverly' (Van Hoof) playing. ${ }^{66}$ But it is precisely this awareness

65 On the issue of time, with particular regard to daemonic time, see the fundamental analysis by Brenk 1996.

66 Van Hoof 2010, 76 n. 31. 
that makes him one of the greatest Platonists of antiquity and one of the most interesting philosophers of his time. ${ }^{67}$

\section{Bibliography}

Aalders, G.J.D. (1982). Plutarch's Political Thought. Amsterdam.

Babut, D. (1984). Le dialogue de Plutarque Sur le démon de Socrate. Essai d'interprétation. $B A G B$, pp. 51-76.

Barigazzi, A. (1994). Una nuova interpretazione del De genio Socratis. In: A. Barigazzi, ed., Studi su Plutarco, Florence, pp. 213-234.

Beck, M., ed. (2014). A Companion to Plutarch. Chichester.

Bénatouil, T., and Bonazzi, M. (2012). Theoria and Bios theoretikos from the Presocratics to the End of Antiquity. An Overview. In: T. Bénatouil and M. Bonazzi, eds., pp. 1-14.

Bénatouil, T., and Bonazzi, M., eds. (2012). Theoria, Praxis and the Contemplative Life after Plato and Aristotle. Leiden.

de Blois, L. (1999). Plutarch's Perception of Plato's Political Activities in Syracuse. In: A. Pérez Jiménez,J. García López, and R.M. Aguilar, eds., Plutarco, Platóny Aristóteles, Madrid, pp. 299-304.

de Blois, L., Bons, J., Kessels, T., and Schenkeveld, D.M., eds. (2004). The Statesman in Plutarch's Works, Vol. ı: Plutarch's Statesman and its Aftermath. Political, Philosophical, and Literary Aspects. Leiden.

Bonazzi, M. (2012a). Plutarch on the Difference between Academics and Pyrrhonists. OSAPh 44, pp. 271-298.

Bonazzi, M. (2012b). Theoria and Praxis. On Plutarch's Platonism. In: T. Bénatouil and M. Bonazzi, eds., pp. 139-161.

Brenk, F. (1996). Time as Structure in Plutarch's The Daimonion of Sokrates. In: L. Van der Stockt, ed., pp. 1-28.

Brenk, F. (2002). Social and Unsocial Memory. The Liberation of Thebes in Plutarch's The Daimonion of Sokrates. In: L. Torraca, ed., Scritti in onore di Italo Gallo, Salerno, pp. 97-113.

Carrière, J.-C., ed. (1984). Plutarque, CEuvres morales, Vol. XI 2. Paris.

Christ, W. (1901). Plutarchs Dialog vom Daimonion des Sokrates. Munich.

Corlu, A., ed. (1970). Plutarque, Le démon de Socrate. Paris.

Croiset, M. (1928). Histoire de la littérature grecque. Paris.

67 A first draft of this paper was presented in October 2013 at St. Andrews Classics Research Seminar; later it greatly benefited from conferences in Leuven in 2015 and in Rome in 2018. Special thanks are due to Pierluigi Donini and to an anonymous reader for many helpful criticisms. 
De Lacy, P.H., and Einarson, B. (1959). Plutarch's Moralia, Vol. 7. Cambridge, MA.

Desideri, P. (1984). Il De genio Socratis di Plutarco. Un esempio di 'storiografia tragica'? Athenaeum 62, pp. 569-585.

Deuse, W. (2010). Plutarch's Eschatological Myths. In: H.-G. Nesselrath, ed., pp. 169-197. Donini, P.L. (2007). Tra Academia e pitagorismo. Il platonismo nel De genio Socratis di Plutarco. In: M. Bonazzi, C. Lévy, and C. Steel, eds., A Platonic Pythagoras. Platonism and Pythagoreanism in the Imperial Age, Turnhout, pp. 99-125.

Donini, P.L. (2011). Il de genio Socratis. I limiti del dogmatismo e quelli dello 'scetticismo'. In: P.L. Donini, Commentary and Tradition. Aristotelianism, Platonism, and Post-Hellenistic Philosophy, Berlin, pp. 403-422.

Donini, P.L., ed. (2017). Plutarco, Il demone di Socrate. Rome.

Dorion, L.A. (1993). La misologie chez Platon. REG 106, pp. 607-618.

Düring, I. (1957). Aristotle in the Ancient Biographical Tradition. Göteborg.

Ferrari, F. (1995). Dio idee materia. La struttura del cosmo in Plutarco di Cheronea. Naples.

Festugière, A.J. (1971). Les trois vies. In: A.J. Festugière, Études de philosophie grecque, Paris, pp. 132-148.

Georgiadou, A. (1995). Vita activa and Vita contemplativa. Plutarch's De genio Socratis and Euripides' Antiope. In: I. Gallo and B. Scardigli, eds., Teoria e prassi politica nelle opere di Plutarco, Naples, pp. 187-199.

Georgiadou, A. (1996). Epameinondas and the Socratic Paradigm in the De genio Socratis. In: L. Van der Stockt, ed., pp. 113-122.

Hahn, J. (1989). Der Philosoph und die Gesellschaft. Selbstverständnis, öffentliches Auftreten und populäre Erwartungen in der hohen Kaiserzeit. Wiesbaden.

Hardie, P. (1996). Sign Language in On the Sign of Socrates. In: L. Van der Stockt, ed., pp. 123-136.

Heath, M. (1989). Unity in Greek Poetics. Oxford.

Hershbell, J. (1988). Plutarch's Portrait of Socrates. ICS 13, pp. 365-381.

Hirzel, R. (1895). Der Dialog. Ein literarhistorischer Versuch. Leipzig.

Jones, C.P. (1971). Plutarch and Rome. Oxford.

Jones, R.M. (1916). The Platonism of Plutarch. Menasha, WI.

Kahle, C. (1912). De Plutarchi ratione dialogorum componendorum, Dissertation, Göttingen.

König J. (2007). Fragmentation and Coherence in Plutarch's Sympotic Questions. In: J. König and T. Whitmarsh, eds., Ordering Knowledge in the Roman Empire, Cambridge, pp. 43-68.

König, J. (2011). Self-Promotion and Self-Effacement in Plutarch's Table Talks. In: F. Klotz and K. Oikonomopoulou, eds., The Philosopher's Banquet. Plutarch's Table Talk in the Intellectual Culture of the Roman Empire, Oxford, pp. 179-202.

Latzarus, B. (1920). Les idées religieuses de Plutarque. Paris. 
Mossman, J. (1997). Introduction. In: J. Mossman, ed., Plutarch and his Intellectual World, London, pp. ix-xii.

Neschke-Hentske, A. (1995). Platonisme politique et théorie du droit naturel. Louvain/ Paris.

Nesselrath, H.-G., ed. (2010). Plutarch, On the daimonion of Socrates. Tübingen.

Nightingale, A. (1995). Genres in Dialogue. Cambridge.

Pelling, C. (1989). Plutarch. Roman Heroes and Greek Culture. In: M. Griffin and J. Barnes, eds., Philosophia togata, Vol. 1: Essays on Philosophy and Roman Society, Oxford, pp. 199-232.

Pelling, C. (2004). Do Plutarch's Politicians Never Learn? In: L. De Blois, J. Bons, T. Kessels, and D.M. Schenkeveld, eds., pp. 87-103.

Pelling, C. (2005). Plutarch's Socrates. Hermathena 179, pp. 125-134.

Pelling, C. (2010). The Liberation of Thebes in Plutarchs' De genio Socratis and Pelopidas. In: H.-G. Nesselrath, ed., pp. 111-127.

Raingeard, P. (1935). Le ПЕРI TOУ ПРО ГЛПОУ de Plutarque. Paris.

Ricard, D. (1844). OEuvres morales de Plutarque. 2nd ed. Paris.

Riley, M. (1977). The Purpose and Unity of Plutarch's De genio Socratis. GRBS 18, pp. 257-273.

Roskam, G. (2002). A Paideia for the Ruler. Plutarch's Dream of Collaboration between Philosopher and Rule. In: P. Stadter and L. Van der Stockt, eds., Sage and Emperor. Plutarch, Greek Intellectuals, and Roman Power in the Time of Trajan (98-117 A.D.), Leuven, pp. 175-189.

Roskam, G., de Pourcq, M., and Van der Stockt, L., eds. (2012). The Lash of Ambition. Leuven.

Sedley, D. (2003). Philodemus and the Decentralisation of Philosophy. Cronache ercolanesi 33, pp. 31-41.

Sieveking, W., ed. (1972). Plutarchi Moralia, Vol. 3. Repr. ed. Leipzig.

Stadter, P. (1999). Drinking, Table Talk, and Plutarch's Contemporaries. In: J.C. Montes Cala, M. Sánchez Ortiz de Landaluce, and R.J. Gallé Cejudo, eds., Plutarco, Dioniso y el vino. Actas del VI Simposio español sobre Plutarco: Cádiz, 14-16 de mayo de 1998, Madrid, pp. 481-49o.

Stoike, D.A. (1975). De genio Socratis. In: H.D. Betz, ed., Plutarch's Theological Writings and Early Christian Literature, Leiden, pp. 236-285.

Swain, S. (1989). Plutarch. Chance, Providence, and History. AJPh 110, pp. 272-302.

Timotin, A. (2012). La démonologie platonicienne. Leiden.

Trapp, M. (2004). Statesmanship in a Minor Key. In: L. de Blois, J. Bons, T. Kessels, and D.M. Schenkeveld, eds., pp. 189-200.

Trapp, M. (2007). Philosophy in the Roman Empire. Ethics, Politics and Society. Aldershot. Van der Stockt, L., ed. (1996). Plutarchea Lovaniensia. A Miscellany of Essays on Plutarch. Leuven. 
Van Hoof, L. (2010). Plutarch's Practical Ethics. The Social Dynamics of Philosophy. Oxford.

Vernière, Y. (1977). Symboles et mythes dans la pensée de Plutarque. Essai d'interprétation philosophique et religieuse des Moralia. Paris.

Wolf, R. (2007). Misology and Truth. Proceedings of the Boston Area Colloquium in Ancient Philosophy 23, pp. 1-16.

Ziegler, K. (1964). Plutarchos von Chaironeia. and ed. Stuttgart. 